\title{
Effect of Launaea procumbens on thyroid glands lipid peroxidation and hormonal dysfunction: a randomized control trial
}

\author{
Rahmat Ali Khan
}

\begin{abstract}
Background: Launaea procumbens (Roxb.) Amin is traditionally used in Pakistan for the treatment of hormonal disorders and oxidative stress. The present study was aimed to evaluate the efficacy of Launaea procumbens methanol extract (LPME) against $\mathrm{KBrO}_{3}$-induced oxidative stress and hormonal dysfunction in thyroid.

Methods: To examine the effects of $\mathrm{LPME}$ against the oxidative stress of $\mathrm{KBrO}_{3}$ in thyroid tissue, 36 male albino rats were used. Protective effects of LPME were observed on thyroid hormonal levels, activities of antioxidant enzymes, lipid peroxidation (TBARS) and DNA damage.

Results: Treatment with $\mathrm{KBrO}_{3}$ significantly $(P<0.01)$ reduced the levels of $\mathrm{T}_{3}(55.13 \pm 1.93)$ and $\mathrm{T}_{4}(14.7 \pm 1.78)$ and increased TSH (55.13 \pm 1.93$)$ levels. $\mathrm{KBrO}_{3}$ exposure in rats reduced the activities of antioxidant enzymes viz:; CAT (1. $16 \pm 0.08)$; SOD (12.0 \pm 0.08$)$, GST (17.7 \pm 1.1$)$ and GSR (54.3 \pm 2.1$)$ but increased lipid peroxidation (20.3 \pm 0.71$)$ and DNA (30.4 \pm 2.0$)$ damage. Co-administration of LPME significantly $(P<0.01)$ improved these alterations with respect to hormonal levels, activities of antioxidant enzymes and lipid peroxidation close to those seen in control rats.
\end{abstract}

Conclusion: These results suggest that LPME can protect thyroid tissue against oxidative damage, possibly through the antioxidant effects of its bioactive compounds.

Keywords: Launaea Procumbens, Oxidative stress, Antioxidant enzymes, $T_{3}, T_{4}$

\section{Background}

Potassium bromate $\left(\mathrm{KBrO}_{3}\right)$ molecular weight $166 \mathrm{~g} / \mathrm{mol}$ is an oxidizing agent. $\mathrm{KBrO}_{3}$ has been used is in industries for the formation of hair solution and cosmetics. Potassium bromate is formed as by product during ozonization of water, causes infections and has been classified as $2 \mathrm{~B}$ group toxic chemical a probable human carcinogen [9]. $\mathrm{KBrO}_{3}$ causes renal cell and thyroid carcinomas in rats, hamsters and mice when exposed chronically [15]. It has been investigated that potassium bromate produces free oxygen radicals which causes oxidative stress and DNA damages [20]. $\mathrm{KBrO}_{3}$ causes nephrotoxicity and hepatotoxicity; decreases the tissue soluble proteins, antioxidant enzymes. The decrease of antioxidant enzymes are due to reactive oxygen species (ROS) produced by metabolism of potassium bromate.

Correspondence: Rahmatgul_81@yahoo.com

Department of Biotechnology, Faculty of Biological Sciences, University of Science and Technology, Bannu, KPK, Pakistan
Potassium bromate depleted GSH content in various tissues which causes decrease in phase II metabolizing enzymes like GSH-Px and glutathione reductase (GSR). It also increases TBARS contents, causes lipid peroxidation and disrupts liver profile including $\gamma$-GT, ALP and protein concentration [4]. Medicinal plants and nutraceuticals play important role in improving human health and phytomedicine [24]. These medicinal plants are composed of some bioactive phytochemical substances, regulates various physiological and molecular action in living organisms. Today many natural products extracted from medicinal plants are being tested for the presence of new drugs with new modes of pharmacological action. Special features of higher plants are their capacity to produce a large number of secondary metabolites [2].

Launaea procumbens (Roxb.)Amin. (Asteraceae) is an annual herb having simple leaves and yellow flowers found in waste places, vacant lots and in cultivated fields throughout Pakistan. Launaea procumbens was used as a 
food and washing agent [27] rheumatism, galactogogues, and increases milk production. Eye redness and itchiness are treated with Launaeaprocumbens and also traditionally used in kidney (painful urination), liver and sexual diseases like gonorrhoea [23]. The antimicrobial activity of ethanolic and aqueous fractions of Launaeaprocumbens was checked against various bacterial and fungal pathogens and reported that proved that ethanolic extract show maximum activity while theaqueous extract was inactive. Launaea procumbensis generly classified as, Kingdom (Plantae), Order (Asterales), Family (Asteraceae), Tribe (Cichorieae), Genus (Launaea), and Species (procumbens). Chemical characterization showed that Launaeaprocumbens composed of salicylic acid, vanllic acid, synergic acid, 2-methyl-resercinol, gallic acid and used against plant pathogenic fungi, nematocides and as allelopathic for inhibition of plant growth [26].

In the present research work we arranged to investigate the protective effects of plant extracts against $\mathrm{KBrO}_{3}$ induced thyroid dysfunctions in rats.

\section{Methods}

\section{Plant collection and extraction}

Launaea procumbens whole plant was collected from District Bannu during summer season 2016. After shad drying of plant at room temperature $\left(25{ }^{\circ} \mathrm{C}\right)$, it was ground mechanically to get fine powder. Among powder, $1 \mathrm{~kg}$ of fine powder was socked in $70 \%$ methanol $(1.5 \mathrm{~L})$ and shacked randomly. After a week the extract was filtered viaWhatman filter paper No.1. Filtrate was concentrated using rotary evaporator at $38{ }^{\circ} \mathrm{C}$ to get methanol crude extractand was kept at $4{ }^{\circ} \mathrm{C}$ in the refrigerator for further in vitro investigation.

\section{Experimental procedure}

Sprague-Dawley male rats were divided into sixteen groups (06 rats). Group 1 was control while Group II received DMSO and saline (0.20\% aqueous $\mathrm{NaCl}$ solution) orally (Wednesday and Saturday) at a dose of $3 \mathrm{ml} / \mathrm{kg}$ b.w. Group III was administered high purity grade $\mathrm{KBrO}_{3}(99.9 \%) 20 \mathrm{mg} / \mathrm{kg}$ b.w in $0.20 \%$ aqueous $\mathrm{NaCl}$ solution (Monday and Thursday) intragastrictly. Group IV and V were given 100; $200 \mathrm{mg} / \mathrm{kg}$ b.w of crude methanol extract (Wednesday and Saturday) of L. procumbens (LPME) after $48 \mathrm{~h}$ of $\mathrm{KBrO}_{3}$ treatment. However, Group VI was given only (LPME) at a dose of $200 \mathrm{mg} / \mathrm{kg}$ b.w (Wednesday and Saturday). All these treatments were given twice a week for 4 weeks. After completion of experiment all the animals were kept on normal feed without any treatment for at least $24 \mathrm{~h}$ before the dissection of animals. Animals were given chloroform anesthesia after urine collection and dissected from ventral side. Blood was collected in the falcon tube and centrifuged for serum and stored in refrigerator. Thyroid glandwas removed and washed in ice cold saline, dried with blotting paper and weighted. After weighing the tissues were divided into two portions. One part was cut off and stored in fixative sera for histology while the other portion was treated with liquid $\mathrm{N}_{2}$ and stored at $-70{ }^{\circ} \mathrm{C}$ for further biochemical and molecular studies.

\section{Serum biochemistry}

Serum level of various hormones viz.; $\mathrm{T}_{3}, \mathrm{~T}_{4}$ and TSHwere calculated through 10,227-Czch Republic (IM1447IM3286) Kit purchased from IMMUNOTECH Company.

\section{Antioxidant oxidant profile}

Eighty mg tissue of thyroid tissue was homogenized in phosphatebuffer for $20 \mathrm{~min}$ at $4{ }^{\circ} \mathrm{C}$ and centrifuged at $10,000 \mathrm{rpm}$ to obtain supernatant. Total tissue protein [16] and antioxidant enzymes like CAT and POD [3], SOD [12], $\gamma$-GT [6], GSH [1], TBARS [11], GSH-Px, GSR and GST $[19,21,22], \mathrm{H}_{2} \mathrm{O}_{2}$, and QR [10] respectively.

\section{Genotoxicity assays}

DNA damages were assessed using protocol of Wu et al. [28] qualitatively as well as quantitatively.

\section{Histopathalogical studies}

Cellular changes were observed light microscope at $40 \times$.

Table 1 Serum biochemistry

\begin{tabular}{llll}
\hline Treatment & $\mathrm{TSH}(\mathrm{ng} / \mathrm{dl})$ & $\mathrm{T}_{4}(\mathrm{ng} / \mathrm{ml})$ & $T_{3}(\mathrm{ng} / \mathrm{ml})$ \\
\hline Control & $35.53 \pm 1.56++$ & $10.0 \pm 2.06++$ & $23.2 \pm 1.87++$ \\
$\mathrm{DMSO}+$ olive oil & $34.67 \pm 1.75++$ & $9.50 \pm 1.04++$ & $22.6 \pm 1.94++$ \\
$20 \mathrm{mg} / \mathrm{kg} \mathrm{KBrO}$ & $6.0 \pm 1.32^{\mathrm{a}}$ & $8.5 \pm 1.24++$ & $14.7 \pm 1.78^{\mathrm{a}}$ \\
$100 \mathrm{mg} / \mathrm{kg} \mathrm{LPME}+\mathrm{KBrO}_{3}$ & $55.13 \pm 1.93^{\mathrm{a}}$ & $9.3 \pm 1.06++$ & $26.43 \pm 2.4++$ \\
$200 \mathrm{mg} / \mathrm{kg} \mathrm{LPME}+\mathrm{KBrO}_{3}$ & $42.07 \pm 1.84++$ & $10.7 \pm 1.19++$ & $24.50 \pm 1.75++$ \\
$200 \mathrm{mg} / \mathrm{kg} \mathrm{LPME}$ alone & $36.87 \pm 2.02++$ & $21.67 \pm 2.16++$ \\
\hline
\end{tabular}

Mean \pm SE ( $n=6$ number)

andicate significance from the control group at $P<0.01$ probability level

++ Indicate significance from the $\mathrm{KBrO}_{3}$ group at $P<0.01$ probability level 
Table 2 Effect of LPME on tissue protein and antioxidant enzymes in thyroid of rat

\begin{tabular}{lllll}
\hline Treatment & Protein $(\mu \mathrm{g} / \mathrm{mg}$ tissue $)$ & CAT $(\mathrm{U} / \mathrm{min})$ & POD $(\mathrm{U} / \mathrm{min})$ & $\mathrm{SOD}(\mathrm{U} / \mathrm{mg} \mathrm{protein})$ \\
\hline Control & $0.57 \pm 0.01++$ & $2.88 \pm 0.09++$ & $8.0 \pm 0.09++$ & $26.17 \pm 0.77++$ \\
$\mathrm{DMSO}+$ olive oil & $0.53 \pm 0.01++$ & $2.90 \pm 0.05++$ & $8.2 \pm 0.05++$ & $25.0 \pm 0.92++$ \\
$20 \mathrm{mg} / \mathrm{kg} \mathrm{KBrO}$ & $0.35 \pm 0.09^{\mathrm{a}}$ & $1.16 \pm 0.08^{\mathrm{a}}$ & $6.3 \pm 0.20^{\mathrm{a}}$ & $12.0 \pm 0.08^{\mathrm{a}}$ \\
$100 \mathrm{mg} / \mathrm{kg} \mathrm{LPME}+\mathrm{KBrO}_{3}$ & $0.58 \pm 0.03++$ & $2.18 \pm 0.04++$ & $7.0 \pm 0.29++$ & $18.3 \pm 0.60++$ \\
$200 \mathrm{mg} / \mathrm{kg} \mathrm{LPME}+\mathrm{KBrO}_{3}$ & $0.52 \pm 0.01++$ & $2.62 \pm 0.03++$ & $7.8 \pm 0.04++$ & $20.10 \pm 1.19++$ \\
$200 \mathrm{mg} / \mathrm{kg} \mathrm{LPME} \mathrm{alone}$ & $0.58 \pm 0.01++$ & $2.93 \pm 0.09++$ & $8.19 \pm 0.08++$ & $28.0 \pm 0.82++$ \\
\hline
\end{tabular}

Mean \pm SE ( $n=6$ number)

${ }^{a}$ Indicate significance from the control group at $P<0.01$ probability level

++ Indicate significance from the $\mathrm{KBrO}_{3}$ group at $P<0.01$ probability level

\section{Statistical analysis}

To determine the treatment effects one way analysis of variance was carried by computer software SPSS 13.0. Level of significance among the various treatments was determined by LSD at $0.05 \%$ level of probability.

\section{Results}

\section{Serum Biochemistry}

Effects of methanol fraction on the serum level of thyroid hormones like TSH, $\mathrm{T}_{3}$ and $\mathrm{T}_{4}$ are shown in Table 1. Treatment of $\mathrm{KBrO}_{3}$ caused reduction in the secretion of $\mathrm{T}_{3}, \mathrm{~T}_{4}$ and increased the secretion of $\mathrm{TSH}$ comparatively to non treated rats. Co-administration of LPME significantly decreased the hormonal secretion in a dose dependent way.

\section{Assessment of antioxidant profile}

Antioxidant enzymes play a crucial role in detoxification of free radicals. $\mathrm{KBrO}_{3}$ induction in rats significantly $(p>0.01)$ decreased the amount of tissue soluble protein and activities of first level antioxidant enzymes viz.; CAT, POD and SOD as compare to control. Postadministration of 100 and $200 \mathrm{mg} / \mathrm{kg}$ b.w., LPME markedly $(p>0.05)$ reduced the intoxication and reversed the changes to normal level (Table 2).
Table 3 revealed the activities of phase II metabolizing enzymes viz.; GST, GSH-Px, GSR, QR, and $\gamma$-GT in various groups. $\mathrm{KBrO}_{3}$-treatment in rats significantly $(p<0.01)$ depleted the activity of GST, GSH-Px, GSR and $\mathrm{QR}$, whereas increased the activity of $\gamma-\mathrm{GT}$ comparatively to control group. The modulation were significantly $(p>0.01)$ reversed by the co-treatment of 100 and $200 \mathrm{mg} / \mathrm{kg}$ b.w., LPME near to control group.

TBARS, $\mathrm{H}_{2} \mathrm{O}_{2}$, GSH and tissue nitrite are key marker of lipid peroxidation and cellular oxidative stress. $\mathrm{KBrO}_{3}$ effects on the content of TBARS, $\mathrm{H} 2 \mathrm{O} 2$, and GSH are shown in Table 4. Administration of $20 \mathrm{mg} / \mathrm{kg}$ b.w., of $\mathrm{KBrO}_{3}$ significantly $(p<0.01)$ reduced the concentrations of $\mathrm{GSH}$ while increased $\mathrm{H}_{2} \mathrm{O}_{2}$ and TBARS as compare to control. TBARS, tissue nitrite was significantly reduced $(\mathrm{p}<0.01)$ by LPME decreased the level of TBARS at 100 and $200 \mathrm{mg} / \mathrm{kg}(p<0.01)$ as compared to $\mathrm{KBrO}_{3}$ group. Level of GSH was improved while $\mathrm{H}_{2} \mathrm{O}_{2}$ was reduced $(p<0.01)$ by LPME at $100 \mathrm{mg} / \mathrm{kg}$ and $200 \mathrm{mg} / \mathrm{kg}$ b.w, respectively.

\section{Thyroid weight and genotoxicity}

Effects of LPME against $\mathrm{KBrO}_{3}$ administration on rats thyroid weight, relative tissue weight and \% DNA fragmentation are shown in Table $5 . \mathrm{KBrO}_{3}$ caused a significant $(p<0.01)$ increased in thyroid tissue

Table 3 Effect of LPME on thyroid GST, GSR, GSH-Px, $y$-GT and QR activity in rat

\begin{tabular}{|c|c|c|c|c|c|}
\hline Treatment & $\begin{array}{l}\text { GSH-Px (nM/mg } \\
\text { protein) }\end{array}$ & $\begin{array}{l}\mathrm{GSR}(\mathrm{nM} / \mathrm{min} / \mathrm{mg} \\
\text { protein) }\end{array}$ & $\begin{array}{l}\mathrm{GST}(\mathrm{nM} / \mathrm{min} / \mathrm{mg} \\
\text { protein) }\end{array}$ & $\begin{array}{l}\text { Y-GT (nM/min/mg } \\
\text { protein) }\end{array}$ & $\begin{array}{l}\mathrm{QR}(\mathrm{nM} / \mathrm{min} / \mathrm{mg} \\
\text { protein) }\end{array}$ \\
\hline Control & $103.3 \pm 2.23++$ & $70.7 \pm 1.9++$ & $41.7 \pm 1.0++$ & $49.3 \pm 3.4++$ & $92.7 \pm 2.9++$ \\
\hline DMSO + olive oil & $102.7 \pm 1.0++$ & $69.3 \pm 2.6++$ & $41.3 \pm 0.9++$ & $49.7 \pm 3.9++$ & $91.2 \pm 2.7++$ \\
\hline $20 \mathrm{mg} / \mathrm{kg} \mathrm{KBrO}$ & $80.3 \pm 2.7^{a}$ & $54.3 \pm 2.1^{a}$ & $17.7 \pm 1.1^{a}$ & $105.5 \pm 1.7^{\mathrm{a}}$ & $72.5 \pm 3.5^{\mathrm{a}}$ \\
\hline $\begin{array}{l}100 \mathrm{mg} / \mathrm{kg} \text { LPME+ } \\
\mathrm{KBrO}_{3}\end{array}$ & $98.3 \pm 1.0++$ & $64.0 \pm 2.9++$ & $34.7 \pm 1.9++$ & $92.3 \pm 2.2++$ & $85.2 \pm 3.3++$ \\
\hline $\begin{array}{l}200 \mathrm{mg} / \mathrm{kg} \text { LPME+ } \\
\mathrm{KBrO}_{3}\end{array}$ & $101.0 \pm 0.7++$ & $69.0 \pm 1.9++$ & $39.5 \pm 0.7++$ & $58.5 \pm 1.4++$ & $91.4 \pm 2.5++$ \\
\hline $\begin{array}{l}200 \mathrm{mg} / \mathrm{kg} \text { LPME } \\
\text { alone }\end{array}$ & $104.7 \pm 2.1++$ & $71.7 \pm 1.8++$ & $41.5 \pm 0.7++$ & $50.3 \pm 2.1++$ & $94.6 \pm 2.6++$ \\
\hline
\end{tabular}

Mean \pm SE ( $n=6$ number)

andicate significance from the control group at $P<0.01$ probability level

++ Indicate significance from the $\mathrm{KBrO}_{3}$ group at $P<0.01$ probability level 
Table 4 Effect of LPME on thyroid GSH, TBARS, $\mathrm{H}_{2} \mathrm{O}_{2}$

\begin{tabular}{|c|c|c|c|}
\hline Treatment & TBARS (nM/min/mg protein & GSH ( $\mu \mathrm{M} / \mathrm{g}$ tissue) & $\mathrm{H}_{2} \mathrm{O}_{2}$ (nM/min/mg tissue) \\
\hline Control & $12.8 \pm 1.14++$ & $0.44 \pm 0.02++$ & $0.86 \pm 0.02++$ \\
\hline DMSO + olive oil & $13.0 \pm 1.06++$ & $0.44 \pm 0.03++$ & $0.85 \pm 0.02++$ \\
\hline $20 \mathrm{mg} / \mathrm{kg} \mathrm{KBrO} 3$ & $20.3 \pm 0.71^{a}$ & $0.67 \pm 0.01^{a}$ & $1.03 \pm 0.01^{a}$ \\
\hline 100 mg/kg LPME+ $\mathrm{KBrO}_{3}$ & $15.3 \pm 1.35++$ & $0.52 \pm 0.04++$ & $0.94 \pm 0.03++$ \\
\hline 200 mg/kg LPME+ KBrO & $13.3 \pm 0.95++$ & $0.44 \pm 0.05++$ & $0.88 \pm 0.03++$ \\
\hline 200 mg/kg LPME alone & $12.0 \pm 0.76++$ & $0.40 \pm 0.06++$ & $0.82 \pm 0.02++$ \\
\hline
\end{tabular}

Mean \pm SE ( $n=6$ number)

${ }^{a}$ Indicate significance from the control group at $P<0.01$ probability level

,+++ Indicate significance from the $\mathrm{KBrO}_{3}$ group at $P<0.01$ probability level

weight and relative thyroid tissue weight and \%DNA damages as compared to non treated control group. Post-treatment of LPME erased the toxic effect of $\mathrm{KBrO}_{3}$ on rat and reduced the thyroid weight, relative tissue weight and \% DNA fragmentation and significantly $(p<0.01)$ reversed towards control group.

\section{Histopathology of thyroid tissue}

Microscopic examinations of various treated groups are shown in Table 6. Administration of $\mathrm{KBrO}_{3}$ caused colloid depletion and cellular hypertrophy, blood vessels congestion, inflammatory cells infiltrations and follicular shape disruptionand follicular cells hyperplasia. Posttreatment with LPME significantly erased the injuries near to control rats.

\section{Discussion}

Thyroid hormones are essential for normal growth of organs, development, function and also regulate hepatocytes metabolism while liver in turn metabolizes thyroid hormones. It means that liver and thyroid hormones are connected with one another, dysfunction of one causes disturbance of other [17]. The hypothalamus releases thyrotrophic-releasing hormone (TRH), which stimulates pituitary gland to release thyroid stimulating hormone (TSH), which in turn promotes thyroid cells to produce thyroid hormones. When level of thyroid hormone is low than TSH and TRH are high, try to increase thyroid hormone and causes risk of thyroid tumor in rats [5]. Our results showed that administration of $\mathrm{KBrO}_{3}$ depleted the secretion of thyroid hormones i.e., $\mathrm{T}_{3}$ and $\mathrm{T}_{4}$ and elevated TSH level in serum of rats which was recovered by LPME. Similar results were reported by Hamidian et al., [7].

The present study revealed that marked changes were induced by $\mathrm{KBrO}_{3}$ in absolute b.w and \% increase in body weight. $\mathrm{KBrO}_{3}$ treatment of rats significantly decreased the b.w, as compare to the non-treated control group. Our results are similar to the findings reported by Farombi et al. [4] that $\mathrm{KBrO}_{3}$ treatment to rat decreases the b.w non significantly as compare to control group. Other study also determined that that low amount of $\mathrm{KBrO}_{3}$ is not toxic as well as mutagenic (Yamaguchi et al., [29]. Increased lipid peroxidation and/or altered non-enzymatic and enzymatic antioxidant systems contributed oxidative stress. Various reports revealed that various enzymatic and non-enzymatic systems in mammalian cell have the capability to reduced ROS and other free radicals [25]. Toxicity induced with $\mathrm{KBrO}_{3}$ results from its metabolism through CYP 450 into free radicals that in turns leads to oxidative damages. In thyroid presence of cytochrome P450 enzyme system has not been established and injuries induced in thyroid are considered indirectly via the production of metabolites in other organs. In the present study induction of $\mathrm{KBrO} 3$ significantly alter the enzymatic level which was reversed by co-treatment of LPME. Similar reports were obtained by the exposure of $\mathrm{KBrO}_{3}$ in rats which has been restored by

Table 5 Effect of LPME on thyroid weight, relative thyroid weight and \% DNA damages

\begin{tabular}{llll}
\hline Treatment & \% DNA fragmentation & Thyroid. weight $(\mathrm{g})$ & Relative thyroid weight (\% to body weight) \\
\hline Control & $3.8 \pm 2.3++$ & $55.3 \pm 2.7++$ & $0.55 \pm 0.02++$ \\
$\mathrm{DMSO}+$ olive oil & $3.9 \pm 2.1++$ & $56.5 \pm 2.2++$ & $0.56 \pm 0.03++$ \\
$20 \mathrm{mg} / \mathrm{kg} \mathrm{KBrO}$ & $79.7 \pm 2.9^{\mathrm{a}}$ & $0.79 \pm 0.09^{\mathrm{a}}$ \\
$100 \mathrm{mg} / \mathrm{kg} \mathrm{LPME}+\mathrm{KBrO}_{3}$ & $7.2 \pm 1.8++$ & $67.8 \pm 2.4++$ & $0.67 \pm 0.04++$ \\
$200 \mathrm{mg} / \mathrm{kg} \mathrm{LPME}+\mathrm{KBrO}_{3}$ & $4.4 \pm 3.8++$ & $57.3 \pm 2.6++$ & $0.57 \pm 0.06++$ \\
$200 \mathrm{mg} / \mathrm{kg} \mathrm{LPME}$ alone & $3.7 \pm 2.6++$ & $56.7 \pm 2.2++$ & $0.56 \pm 0.02++$ \\
\hline
\end{tabular}

Mean \pm SE ( $n=6$ number)

andicate significance from the control group at $P<0.01$ probability level

++ Indicate significance from the $\mathrm{KBrO}_{3}$ group at $P<0.01$ probability level 
Table 6 Effect of LPME on thyroid histopathology

\begin{tabular}{|c|c|c|c|c|c|}
\hline Treatment & Colloids depletion & Hyper-Trophy & Hyperplasia & Blood vessel congestion & $\begin{array}{l}\text { Degeneration of follicular } \\
\text { architecture }\end{array}$ \\
\hline Control & - & - & - & - & - \\
\hline DMSO + olive oil & - & - & - & - & - \\
\hline $20 \mathrm{mg} / \mathrm{kg} \mathrm{KBrO} 3$ & +++ & +++ & +++ & +++ & +++ \\
\hline 100 mg/kg LPME+ $\mathrm{KBrO}_{3}$ & - & $-/+$ & - & -+ & $-/+$ \\
\hline 200 mg/kg LPME+ $\mathrm{KBrO}_{3}$ & - & - & - & -+ & - \\
\hline 200 mg/kg LPME alone & - & - & - & - & - \\
\hline
\end{tabular}

-, normal; -/+, mild; ++, medium; +++, severely damaged

supplementation of Ficus racemosa and a natural antioxidant kolaviron [14]. Free radicals react with DNA to form a mutagenic pirimedopurinone adduct (M1G) of deoxyguanosine [18] causes genomic instability and damages. The data revealed that the treatment of $\mathrm{KBrO}_{3}$ causes significant oxidative DNA damage in thyroid tissue of rats which are reversed by LPME. Similar investigation was reported by Khan et al., [13] during study of protective effects of Digeramuricata. These results show that the extract contains bioactive phenolic and poly phenolic compounds which play important role in DNA repair. Data of the present study revealed that $\mathrm{KBrO}_{3}$ treatment in rats caused colloids depletion and hypertrophy, blood vessels congestion, follicular shape degradation and hyperplasia in thyroid. Treatment with LPME significantly erased the injuries. Similar observation was reported by Hooth et al. [8] during drinking water exposure of sodium chlorate in rats.

\section{Abbreviations}

GSR: Glutathione reductase; $\mathrm{KBrO}_{3}$ : Potassium bromate; ROS: Reactive oxygen species; TRH: Thyrotrophic-releasing hormone; TSH: Thyroid stimulating hormone

\section{Acknowledgements}

We thankful to all my friends and college who guided me.

\section{Funding}

No funding is received for conduction of the study.

Availability of data and materials

Data and material will be available as per Journal rule.

\section{Authors' contributions}

RAK (ORCID ID: 0000-0003-0453-2090) completed experimentations and analysis of data as well as considerable influence to outset and design, analysis of data and drafting of manuscript.

Ethics approval and consent to participate

The study was conducted according to the protocol approved by ethical committee of the University.

\section{Consent for publication}

All the authors are agreeing to submit the paper in your esteemed Journal.

\section{Competing interests}

The author declares that he/she has no competing interests.

\section{Publisher's Note}

Springer Nature remains neutral with regard to jurisdictional claims in published maps and institutional affiliations.

Received: 16 May 2017 Accepted: 31 August 2017

Published online: 11 September 2017

References

1. Carlberg I, Mannervik EB. Glutathione level in rat brain. J Biol Chem. 1975; 250:4475-80.

2. Castello MC, Phatak A, Chandra N, Sharon M. Antimicrobial activity of crude extracts from plant parts and corresponding calli of BixaorellanaL. Indian J Exp Biol. 2002:1378-81.

3. Chance B, Maehly AC. Assay of catalase and peroxidases. Methods Enzymol. 1955:11:764-75

4. Farombi EO, Alabi MC, Akuru TO. Kolaviron modulates cellular redox status and impairment of membrane protein activities induced by potassium bromate $\left(\mathrm{KBrO}_{3}\right)$ in rats. Pharmacol Res. 2002;45:63-8.

5. Glatt CM, Ouyang M, Welsh W, Green JW, Connor JO, Frame SR, Everds NE, Piondexter G, Snajdr S, Delker DA. Molecular charterization of thyroid toxicity; anchoring gene expression profile to biochemical and pathological end points. Environ Health Perspect. 2005;113:1354-61.

6. Habig WH, Pabst MJ, Jakoby WB. Glutathione-S-transferases: the first enzymatic step in mercapturic acid formation. J Biol Chem. 1974;249:7130-9.

7. Hamidian G, Alboghobeish N, Varzi NH, Esmaeilzadeh S. Unbiased stereological and histological study of silymarin effects on hamster adrenocortical structure in response to an exogenous glucocorticoid. J Cell Anim Biol. 2009:3:107-12.

8. Hooth MJ, Deagelo AB, George MH, Gaillard ET, Travlos GS, Boorman GA, Wolf DC. Subchronic sodium chlorate exposure in drinking water results in concentration dependent increase in rat thyroid follicular cell hyperplasia. J Toxicol Pathol. 2001:29:250-62.

9. IARCMorld Health Organisation. IARC Monographs on the evaluation of the carcinogenic risk of chemicals to humans. Some naturally occurring and synthetic food components, furocoumarins and ultraviolet radiation. Lyon, France: IARC publication no. 40; 1986. p. 207-20.

10. Iqbal M, Sharma SD, Zadeh HR, Hasan N, Abdulla M, Athar M. Glutathione metabolizing enzymes and oxidative stress in ferric nitrilotriacetate (Fe-NTA) mediated hepatic injury. Redox Rep. 1996;2:385-91.

11. Jollow DJ, Mitchell JR, Zampaglione N, Gillete JR. Bromobenzene induced liver necrosis. Protective role of glutathione and evidence for 3, 4-bromobenzene oxide as a hepatotoxic metabolite. Pharmacology. 1974:11:151-69.

12. Kakkar P, Das B, Viswanathan PN. A modified spectrophotometric assay of superoxide dimutase. Indian J Biochem Biophys. 1984;21:130-2.

13. Khan MR, Ahmed D. Protective effects of Digeramuricata (L.)Mart.On testis against oxidative stress of carbon tetrachloride in rat. Food Chem Toxicol. 2009:47:1393-9.

14. Khan N, Sultana S. Chemomodulatory effect of Ficusracemosa extract against chemically induced renal carcinogenesis and oxidative damage response in Wister rats. Life Sci. 2005:77:1194-210.

15. Kurokawa Y, Maekawa A, Takahashi M, Hayashi Y. Toxicity and carcinogenicity of potassium bromate-a new renal carcinogen. Environ Health Perspect. 1990;87:309-35.

16. Lowry $\mathrm{OH}$, Rosenberg NJ, Farr AL, Randall RJ. Protein measurement with Folin phenol reagent. J Biol Chem. 1951;193:265-75. 
17. Malik R, Hodgson $\mathrm{H}$. The relationship between thyroid gland and the liver. J Med. 2002;95:559-69.

18. Marnett JL. Oxyridicals and DNA damage. Carcinogenesis. 2000;21:361-70.

19. Mohandas J, Marshal JJ, Duggin GG, Horvath JS, Tiller DJ. Differential distribution of glutathione and glutathione-related enzymes in rabbit kidney. Possible implications in analgesic nephropathy. Biochem Pharmacol. 1984;33:1801-7.

20. Murata M, Bansho Y, Inoue S, Ito K, Ohnishi S, Midorikawa K, Kawanashi S. Requirement of glutathione and cysteine in guanine-specific oxidation of DNA by carcinogenic potassium bromate. Chem Res Toxicol. 2001;14:678-85.

21. Orlowaski M, Miester A. $y$-Glutamylcyclotransferase distribution, isozymic forms, and specificity. J Biol Chem. 1973;248:2836-44.

22. Pick A, Keisari Y. Superoxide anion and hydrogen peroxide production by chemically elicited peritoneal macrophages-induction by multiple nonphagocytotic stimuli. Cell Immunol. 1981;59:301-18.

23. Qureshi R, Raza BG. Ethnobotany of plants used by the Thari people of Nara Desert, Pakistan. Fitoterapia. 2008;79:468-73.

24. Scicchitano P, Cameli M, Maiello M, Modesti PA, Muiesan ML, Novo S. Nutraceuticals and dyslipidaemia: beyond the common therapeutics. J Funct Foods. 2014;6:11-32.

25. Sahreen S, Khan MR, Khan RA. Evaluation of antioxidant profile of various solvent extracts of Carissa opaca leaves: an edible plant. Chem Central J. 2017:(11):83-11.

26. Shaukat SS, Siddiqui IA, Nasim AI. Nematocidal, allelophatic and antifuga potential of Launaeaprocumbens. PakistanJ Plant Pathol. 2003;2:181-93.

27. Wazir SM, Saima S, Dasti AA, Subhan S. Ethanobotnical importance of salt range species of district karak, Pakistan. PakistanJ Plant Sci. 2007:13:29-31.

28. Wu B, Ootani A, Iwakiri R, Sakata Y, Fujise T, Amemori S, Yokoyama F, Tsunada S, Fujimoto K. T cell deficiency leads to liver carcinogenesis in Azoxymethane-treated rats. Exp Biol Med. 2005;231:91-8.

29. Yamaguchi T, Wei M, Hagihara N, Omori M, Wanibuchi H, Fukushima S. Lack of mutagenic and toxic effects of low dose potassium bromate on kidneys in the big blue rat. Mutat Res. 2008;652:1-11.

\section{Submit your next manuscript to BioMed Central and we will help you at every step:}

- We accept pre-submission inquiries

- Our selector tool helps you to find the most relevant journal

- We provide round the clock customer support

- Convenient online submission

- Thorough peer review

- Inclusion in PubMed and all major indexing services

- Maximum visibility for your research

Submit your manuscript at www.biomedcentral.com/submit

) Biomed Central 